\title{
Effects of Saccharomyces cerevisiae-based direct-fed microbial and exogenous enzyme products on enteric methane emission and productivity in lactating dairy cows
}

\author{
J. Oh, ${ }^{1}$ M. Harper, ${ }^{1}$ A. Melgar, ${ }^{1}$ D. M. Paulus Compart, ${ }^{2}$ and A. N. Hristov ${ }^{1 *}$ \\ ${ }^{1}$ Department of Animal Science, The Pennsylvania State University, University Park 16802 \\ ${ }^{2} \mathrm{PMI}$ Nutritional Additives, Arden Hills, MN 55126
}

\section{ABSTRACT}

The objective of this experiment was to investigate the effects of a Saccharomyces cerevisiae-based directfed microbial product (SDM) and an exogenous enzyme product (ENZ) on enteric methane emission, milk yield and composition, total-tract digestibility of nutrients, ruminal fermentation, and nitrogen excretion and secretion in lactating dairy cows. Eighteen Holstein cows were used in a $3 \times 3$ Latin square design experiment with three 28 -d periods. Treatments were (1) control (no additive), (2) $28 \mathrm{~g}$ of SDM/d per cow, or (3) $10 \mathrm{~g}$ of ENZ/d per cow. Treatments were top-dressed at the time of feeding. The basal diet consisted of (dry matter basis) $60 \%$ forage and $40 \%$ concentrates and contained $16.5 \%$ crude protein and $32.0 \%$ neutral detergent fiber. Treatments had no effect on enteric methane production, yield (methane per kg of dry matter intake, DMI), or intensity (methane per $\mathrm{kg}$ of energy-corrected milk yield). Carbon dioxide production was similar among treatments. Compared with control, SDM increased milk yield by $2 \mathrm{~kg} / \mathrm{d}$ without affecting DMI or feed efficiency. Supplementation of the diet with ENZ did not affect DMI, milk yield, or feed efficiency. Concentrations and yields of milk fat, true protein, and lactose, and energy-corrected milk yield were not different among treatments. Neither SDM nor ENZ had an effect on total-tract digestibility of nutrients or nitrogen excretion and secretion. Concentration of total volatile fatty acids (VFA) in ruminal fluid was increased by both SDM and ENZ, and rumen pH was decreased by SDM compared with the control. At levels similar to the control DMI, the increased concentration of VFA in ruminal fluid of cows receiving SDM suggests an increased postruminal supply of energy and may partly explain the increased milk yield with that treatment. However, it is important to note that milk composition

Received September 26, 2018.

Accepted March 11, 2019.

*Corresponding author: anh13@psu.edu and energy-corrected milk yield were not affected by treatment.

Key words: direct-fed microbial, exogenous enzyme, rumen fermentation, dairy cow

\section{INTRODUCTION}

Enteric methane produced during microbial fermentation in the rumen not only represents a loss of feed energy but it is also a major greenhouse gas contributing to climate change (Johnson and Johnson, 1995; IPCC, 2014). Enteric methane emissions from ruminants represent 2 to $12 \%$ of the animal's gross energy intake and approximately $4 \%$ of global anthropogenic greenhouse gas emissions (Johnson and Johnson, 1995; IPCC, 2014). Dietary interventions have been studied to mitigate enteric methane emission, with methane inhibitors (e.g., 3-nitrooxypropanol), electron receptors (e.g., nitrates), and dietary lipids being examples of successful mitigants (Hristov et al., 2013; Patra, 2016).

Direct-fed microbials (DFM) and exogenous enzymes (EXE) have different modes of action in the rumen. Direct-fed microbials are primarily yeast-based and their suggested mode of action is stabilization of ruminal fermentation by increasing ruminal $\mathrm{pH}$, oxygen scavenging, and provision of soluble growth factors (Newbold et al., 1996; Callaway and Martin, 1997; Chaucheyras-Durand et al., 2008). Exogenous enzymes, on the other hand, are expected to contribute to degradation of carbohydrate (fiber and starch) and protein in the rumen according to their activities (Meale et al., 2014). Effects of DFM (Chaucheyras-Durand et al., 2008; Desnoyers et al., 2009) and EXE (Beauchemin and Holtshausen, 2011; Adesogan et al., 2014; Sujani and Seresinhe, 2015) on milk production in dairy cows have been extensively studied but responses are inconsistent. In a meta-analysis of EXE studies, Arriola et al. (2017) observed small trends for improved total-tract apparent fiber digestibility and milk production but also emphasized the large variability in the data. One apparent reason for these variable responses is that 
DFM and EXE largely differ in composition and activities and have been applied at various doses and using different application methods (Meale et al., 2014). New recombinant EXE are being developed and successfully tested in preliminary in vitro experiments (Ribeiro et al., 2018).

Through their effects on ruminal fermentation, DFM and EXE have been suggested as potential mitigants of enteric methane emission (Grainger and Beauchemin, 2011; McAllister et al., 2011; Hristov et al., 2013). An in vitro study demonstrated that Saccharomyces cerevisiae extract increased hydrogen utilization by acetogens and decreased methane production (Chaucheyras et al., 1995). Additionally, positive effects of DFM and EXE on milk yield and feed efficiency may decrease methane yield (per $\mathrm{kg}$ of DMI) and intensity (per $\mathrm{kg}$ of milk or ECM) in lactating cows (Hristov et al., 2013; Arriola et al., 2017). Although the effects of DFM and EXE on enteric methane emission have been studied in vitro (He et al., 2015; Elanthamil and Bandeswaran, 2017; Mohamed et al., 2017), experiments with lactating dairy cows are scarce.

Therefore, we hypothesized that DFM and EXE, through their beneficial effects on ruminal fermentation and carbohydrate degradability, could decrease enteric methane production, yield, or intensity in lactating dairy cows. The objective of the experiment was to investigate the effects of a Saccharomyces cerevisiae-based DFM and an enzyme extract from Aspergillus oryzae and Aspergillus niger on enteric methane emission, milk production and composition, total-tract digestibility of nutrients, ruminal fermentation, and $\mathrm{N}$ excretion and secretion in dairy cows.

\section{MATERIALS AND METHODS}

\section{Animals and Treatments}

The Pennsylvania State University Institutional Animal Care and Use Committee approved all procedures used in this experiment.

The experiment was conducted at The Pennsylvania State University's Dairy Teaching and Research Center. Eighteen lactating Holstein cows, including 6 rumen-cannulated (10-cm internal diameter cannulas; Bar Diamond Inc., Parma, ID) cows, were used in a $3 \times$ 3 Latin square design experiment balanced for residual effects. Cows had average milk yield of $39 \pm 10.2 \mathrm{~kg} / \mathrm{d}$, DIM of $115 \pm 42.0 \mathrm{~d}$, and BW of $609 \pm 77.9 \mathrm{~kg}$ at the beginning of the experiment. Cows were housed in a tiestall barn and had free access to drinking water. The experiment consisted of 3 periods; each period lasted 28 $\mathrm{d}$, including $21 \mathrm{~d}$ for adaptation to treatment and $7 \mathrm{~d}$ for data and sample collections. Feeds were offered as
TMR once daily in the morning at approximately 0800 h. All cows were fed the same basal TMR offered ad libitum, targeting 10\% refusals. The basal diet (Table 1) was formulated to meet or exceed the nutrient requirements (NRC, 2001) of cows with BW of $680 \mathrm{~kg}$ and milk yield of $39.5 \mathrm{~kg} / \mathrm{d}$ (with $3.80 \%$ fat and $3.20 \%$ true protein) at a DMI of $27.3 \mathrm{~kg} / \mathrm{d}$. Treatments were (1) control (basal diet with no additives), (2) $28 \mathrm{~g} /$ cow per day of a $S$. cerevisiae-based DFM product (FortiShield, PMI Nutritional Additives, Arden Hills, MN; SDM), and (3) $10 \mathrm{~g} /$ cow per day of an enzyme extract from Aspergillus oryzae and Aspergillus niger (CelluloGest, PMI Nutritional Additives; ENZ). The DFM product contained $1.8 \times 10^{9} \mathrm{cfu} / \mathrm{g}$ of $S$. cerevisiae and $1.1 \times$ $10^{8} \mathrm{cfu} / \mathrm{g}$ of a mixture of Lactococcus lactis, Bacillus subtilis, Enterococcus faecium, and Lactobacillus casei. The ENZ product contained amylase $\left(1.2 \times 10^{6}\right.$ modified Wohlgemuth units $/ \mathrm{kg})$, hemicellulase $\left(1.9 \times 10^{5}\right.$ hemicellulase units $/ \mathrm{kg})$, cellulase $\left(1.1 \times 10^{4}\right.$ cellulase units $/ \mathrm{kg})$, glucanase $\left(1.0 \times 10^{3}\right.$ glucanase units $\left./ \mathrm{kg}\right)$, and pectinase $\left(1.0 \times 10^{3}\right.$ pectinase units $\left./ \mathrm{kg}\right)$. Doses of SDM and ENZ were based on the manufacturer's recommendation. Treatments were top-dressed daily and mixed with approximately $500 \mathrm{~g}$ of TMR. All cows were milked twice daily at 0600 and $1800 \mathrm{~h}$.

\section{Sampling and Analyses}

Individual feed intake, milk yield, and BW (AfiFarm 3.04E scale system; S.A.E. Afikim, Rehovot, Israel) of the cows were recorded daily during the entire experiment. Samples were collected from TMR and refusals twice weekly and composited per experimental period for further analyses. Forages and concentrate feeds were sampled weekly and composited per experimental period for further analyses. Composite samples of the TMR, forages, and concentrate feeds were stored at $-20^{\circ} \mathrm{C}$, oven-dried (at $65^{\circ} \mathrm{C}$ ) to constant weight, and ground through a 1-mm sieve (Wiley mill, Thomas Scientific, Swedesboro, NJ) for analyses of CP (AOAC International, 2000), NDF (Van Soest et al., 1991), ADF (AOAC International, 2000), ether extract (AOAC International, 2006), Ca (AOAC International, 2000), $\mathrm{P}$ (AOAC International, 2000), and estimated NFC (NRC, 2001) and $\mathrm{NE}_{\mathrm{L}}$ (NRC, 2001) by Cumberland Valley Analytical Services (Waynesboro, PA). Analysis of $\mathrm{OM}$ was conducted by ashing the feed samples for $4 \mathrm{~h}$ at $600^{\circ} \mathrm{C}$. Starch was analyzed as described in Hall (2009). The nutrient analyses of the individual feed ingredients and their inclusion rate were used to estimate nutrient content of the diets.

Milk samples were collected from p.m. and a.m. milkings on d 26 and 27 of each experimental period. Milk samples were preserved with 2-bromo-2-nitropro- 
Table 1. Ingredient and chemical composition of diets fed in the experiment

\begin{tabular}{|c|c|}
\hline Item & Diet \\
\hline \multicolumn{2}{|l|}{ Ingredient, $\%$ of $\mathrm{DM}$} \\
\hline Corn silage $^{1}$ & 44.5 \\
\hline Alfalfa haylage ${ }^{2}$ & 10.5 \\
\hline Grass hay & 4.95 \\
\hline Whole cottonseed & 2.10 \\
\hline Corn grain, ground & 7.92 \\
\hline Soybean seeds, whole heated ${ }^{3}$ & 9.00 \\
\hline Canola meal $^{4}$ & 11.87 \\
\hline Soybean meal ${ }^{5}$ & 2.47 \\
\hline Molasses $^{6}$ & 4.95 \\
\hline Vitamin and mineral premix ${ }^{7}$ & 1.69 \\
\hline \multicolumn{2}{|c|}{ Composition, ${ }^{8} \%$ of DM (or as indicated) } \\
\hline $\mathrm{CP}^{8}$ & 16.9 \\
\hline $\mathrm{RDP}^{9}$ & 11.5 \\
\hline RUP $^{9}$ & 5.4 \\
\hline $\mathrm{NDF}^{8}$ & 29.3 \\
\hline $\mathrm{ADF}^{8}$ & 18.5 \\
\hline $\operatorname{Starch}^{8}$ & 26.7 \\
\hline $\mathrm{NE}_{\mathrm{L}}$, Mcal $/ \mathrm{kg}^{9}$ & 1.64 \\
\hline Ether extract ${ }^{8}$ & 5.4 \\
\hline $\mathrm{Ash}^{8}$ & 5.5 \\
\hline $\mathrm{Ca}^{8}$ & 0.8 \\
\hline $\mathrm{P}^{8}$ & 0.4 \\
\hline $\mathrm{NFC}^{9}$ & 45.3 \\
\hline $\mathrm{NE}_{\mathrm{L}}$ balance, ${ }^{10} \mathrm{Mcal} / \mathrm{d}$ & $(2.6,2.5,2.6)$ \\
\hline MP balance, ${ }^{10} \mathrm{~g} / \mathrm{d}$ & $(-92,-149,-125)$ \\
\hline
\end{tabular}

${ }^{1}$ Corn silage was $46.8 \% \mathrm{DM}$ and contained (DM basis) $7.4 \% \mathrm{CP}, 33.2 \%$ $\mathrm{NDF}$, and $38.4 \%$ starch.

${ }^{2}$ Alfalfa haylage was $40.1 \% \mathrm{DM}$ and contained (DM basis) $21.3 \% \mathrm{CP}$ and $39.9 \% \mathrm{NDF}$.

${ }^{3}$ Soybean seeds contained (DM basis) $37.4 \% \mathrm{CP}$.

${ }^{4}$ Canola meal contained (DM basis) $42.4 \% \mathrm{CP}$.

${ }^{5}$ Soybean meal contained (DM basis) $46.6 \% \mathrm{CP}$.

${ }^{6}$ Molasses (Westway Feed Products, Tomball, TX) contained (DM basis) $3.9 \% \mathrm{CP}$ and $66 \%$ total sugar.

${ }^{7}$ The premix (Cargill Animal Nutrition, Cargill Inc., Roaring Spring, PA) contained (\%, as-is basis) trace mineral mix, $1.88 ; \mathrm{MgO}(54 \%$ $\mathrm{Mg}$ ), 8.0; NaCl, 24.9; vitamin ADE premix (Cargill Animal Nutrition, Cargill Inc.), 0.41; limestone, 36.8; selenium, 0.13; and dry corn distillers grains with solubles, 29.0. Ca, $14.4 \%$;, $0.75 \% ; \mathrm{Mg}, 2.48 \%$; $0.28 \%$; S, 0.50\%; Se, $12.8 \mathrm{mg} / \mathrm{kg}$; Cu, $651 \mathrm{mg} / \mathrm{kg} ; \mathrm{Zn}, 3,433 \mathrm{mg} / \mathrm{kg} ; \mathrm{Fe}$, $798 \mathrm{mg} / \mathrm{kg}$, vitamin A, 195,290 IU/kg; vitamin D, 62,500 IU/kg; and vitamin $\mathrm{E}, 1,863 \mathrm{IU} / \mathrm{kg}$.

${ }^{8}$ Values calculated using the chemical analysis (Cumberland Valley Analytical Services Inc., Waynesboro, PA) of the individual feed ingredients and their inclusion rate in the diets.

${ }^{9}$ Estimated based on NRC (2001).

${ }^{10}$ Estimated based on NRC (2001) using actual DMI, milk yield, milk composition, and $\mathrm{BW}$ of the cows throughout the experiment for the control, SDM, and ENZ treatments, respectively. SDM = Saccharomyces cerevisiae-based direct-fed microbial product at $28 \mathrm{~g} /$ cow per day; ENZ = exogenous enzyme product at $10 \mathrm{~g} /$ cow per day.

pane-1,3 diol and submitted to Dairy One Cooperative Inc. (Ithaca, NY) for analysis of milk fat, true protein, lactose, SCC, MUN, other solids, and total solids using infrared spectroscopy (MilkoScan 4000; Foss Electric, Hillerød, Denmark). Milk composition data were weighted for the corresponding p.m. and a.m. milk yields.
Enteric methane and carbon dioxide emissions were measured using the GreenFeed system (C-Lock Inc., Rapid City, SD) as described in Hristov et al. (2015). Gas measurements were collected 8 times on 3 consecutive days as follows: at 0900, 1500, and $2100 \mathrm{~h}$ (d 24), 0300, 1200, and $1700 \mathrm{~h} \mathrm{(d} \mathrm{25),} \mathrm{and} 0000$ and $0500 \mathrm{~h} \mathrm{(d}$ 26) during wk 4 of each experimental period. A cannula extension (C-Lock Inc.) was used for the rumen-cannulated cows to capture potential gas leaking through the cannula (Lopes et al., 2016). Enteric gas emissions were also calculated on DMI, milk yield, and ECM bases.

Ruminal samples were collected from the cannulated cows (2 per treatment in each period) on d 27 and 28 at 0 (before feeding), 3, 6, 12, 18, and $24 \mathrm{~h}$ after feeding. Whole-rumen contents were collected from 5 locations within the rumen (2 samples from the feed mat, 1 from the reticulum, and 2 from the ventral sac). Whole-rumen contents were filtered through 2 layers of cheesecloth to obtain approximately $300 \mathrm{~mL}$ of filtrate, and the $\mathrm{pH}$ of the filtrate was measured immediately. An aliquot of filtrate $(5 \mathrm{~mL})$ was mixed with a protozoal staining solution (MFS solution, Ogimoto and Imai, 1981), composited per cow and period, stored at $4^{\circ} \mathrm{C}$, and processed for protozoal counts as described in Hristov et al. (2001). The remaining filtrate $(45 \mathrm{~mL})$ was centrifuged at low speed $\left(500 \times g\right.$ for 5 min at $\left.4^{\circ} \mathrm{C}\right)$ to remove protozoa and feed particles. Aliquots of the supernatant $(6 \mathrm{~mL})$ were mixed with $0.5 \mathrm{~mL}$ of chilled $65 \%$ trichloroacetic acid to acidify the sample and precipitate proteins. The acidified samples were stored frozen $\left(-20^{\circ} \mathrm{C}\right)$ and later thawed and centrifuged at 20,000 $\times g$ for $15 \mathrm{~min}$ at $4^{\circ} \mathrm{C}$; the supernatant was analyzed for ammonia according to Chaney and Marbach (1962). Another set of aliquots from the low-speed supernatant was combined with $1 \mathrm{~mL}$ of $25 \%$ metaphosphoric acid and $1 \mathrm{~mL}$ of $0.6 \%$ 2-ethyl-butyric acid (internal standard), kept frozen $\left(-20^{\circ} \mathrm{C}\right)$, and later thawed and used for VFA analysis after centrifugation at 20,000 $\times g$ for $15 \mathrm{~min}$ at $4^{\circ} \mathrm{C}$. Volatile fatty acids were analyzed using a GC (Agilent 7890A, Agilent, Santa Clara, CA). Separation was achieved by a custom packed column $(1.8 \mathrm{~m}$ $\times 6.4 \mathrm{~mm}$, Supelco Inc., Bellefonte, PA) operated at a flow rate of $15 \mathrm{~mL} / \mathrm{min}$ and $125^{\circ} \mathrm{C}$. Detection of VFA was conducted by a flame-ionization detector at $225^{\circ} \mathrm{C}$.

Fecal samples (approximately $400 \mathrm{~g}$ per sample) were collected at 8 times in $3 \mathrm{~d}$ during each experimental period as follows: 1000, 1600, and $2200 \mathrm{~h} \mathrm{(d} \mathrm{24),} \mathrm{0400,}$ 1300, and $1900 \mathrm{~h} \mathrm{(d} \mathrm{25),} \mathrm{and} 0100$ and $0700 \mathrm{~h} \mathrm{(d} \mathrm{26).}$ Samples were processed for DM, OM, CP, NDF, ADF, and starch analyses as described in Oh et al. (2013); starch was analyzed as for the feed samples. Apparent total-tract digestibility of DM, OM, CP, NDF, ADF, and starch was estimated using indigestible NDF (12-d rumen incubation) as an intrinsic marker [Huhtanen 
et al., 1994; except that 25- $\mu \mathrm{m}$-pore-size filter bags (Ankom Technology, Macedon, NY) were used for the ruminal incubation]. Urine samples (approximately 300 $\mathrm{mL}$ per sample) were collected at the same time points as for fecal samples and processed as described in $\mathrm{Oh}$ et al. (2013). Urine was analyzed for total N, urea$\mathrm{N}$, allantoin, uric acid, and creatinine as described in Hristov et al. (2011). Purine derivatives (PD), allantoin and uric acid, were used as indicators of ruminal microbial synthesis. Daily urine volume and urinary $\mathrm{N}$ and urea-N excretions were estimated based on urinary creatinine concentration with a creatinine excretion rate of $29 \mathrm{mg} / \mathrm{kg}$ of $\mathrm{BW}$, estimated from total urine collections (Hristov et al., 2011).

\section{Statistical Analysis}

All data were analyzed using SAS version 9.3 (2003; SAS Institute Inc., Cary, NC). Outliers were removed with the REG procedure based on an absolute studentized residual value $>3$. Data were tested for normality using the UNIVARIATE procedure. Milk yield, DMI, and estimated feed efficiency data for the last $7 \mathrm{~d}$ of each experimental period were used in the statistical analysis. Averaged milk yield and milk composition data were used to calculate yields of milk fat, true protein, lactose, and ECM. Rumen fermentation data were averaged per day and the average data were used in the statistical analysis. All data were analyzed using the MIXED procedure.

Data for gas emissions, milk composition, digestibility, protozoa counts, and $\mathrm{N}$ excretion and secretion were analyzed by ANOVA Latin square. The model used was as follows:

$$
\mathrm{Y}_{\mathrm{ijkl}}=\mu+\mathrm{S}_{\mathrm{i}}+\mathrm{C}(\mathrm{S})_{\mathrm{ij}}+\mathrm{P}_{\mathrm{k}}+\mathrm{T}_{1}+\mathrm{e}_{\mathrm{ijkl}},
$$

where $Y_{\mathrm{ijk}}$ is the dependent variable, $\mu$ is the overall mean, $\mathrm{S}_{\mathrm{i}}$ is the square, $\mathrm{C}(\mathrm{S})_{\mathrm{ij}}$ is the cow within square, $\mathrm{P}_{\mathrm{k}}$ is the kth period, $\mathrm{T}_{1}$ is the lth treatment, and $\mathrm{e}_{\mathrm{ijkl}}$ is the error term. Square and cow within square were random effects and all others were fixed.

Dry matter intake, milk yield, feed efficiency, and rumen fermentation data ( $\mathrm{pH}, \mathrm{VFA}$, and ammonia) were analyzed as repeated measures assuming a first-order autoregressive $[\mathrm{AR}(1)]$ covariance structure. The model used was as follows:

$$
\begin{aligned}
\mathrm{Y}_{\mathrm{ijklm}}=\mu+ & \mathrm{S}_{\mathrm{i}}+\mathrm{C}(\mathrm{S})_{\mathrm{ij}}+\mathrm{P}_{\mathrm{k}}+\mathrm{T}_{1}+\mathrm{D}_{\mathrm{m}} \\
& +\mathrm{TD}_{\mathrm{lm}}+\mathrm{e}_{\mathrm{ijk} \mathrm{km}},
\end{aligned}
$$

where $Y_{i j k l m}$ is the dependent variable, $\mu$ is the overall mean, $\mathrm{S}_{\mathrm{i}}$ is the square, $\mathrm{C}(\mathrm{S})_{\mathrm{ij}}$ is the cow within square,
$\mathrm{P}_{\mathrm{k}}$ is the kth period, $\mathrm{T}_{1}$ is the lth treatment, $\mathrm{D}_{\mathrm{m}}$ is the time effect, $\mathrm{TD}_{\operatorname{lm}}$ is the treatment $\times$ time interaction, and $\mathrm{e}_{\mathrm{ijk} \mathrm{jl}}$ is the error term. Square and cow within square were random effects and all others were fixed.

Where the main effect of treatment was significant, means were separated by pairwise $t$-test (pdiff option of PROC MIXED). Statistical differences were declared at $P<0.05$. Differences between treatments at $0.05 \leq P$ $<0.10$ were considered as a trend toward significance. Data are presented as least squares means.

\section{RESULTS AND DISCUSSION}

\section{Enteric Methane Emission}

Enteric methane and carbon dioxide emissions were not affected by treatment in the current experiment (Table 2). Methane emission was similar among treatments when calculated on the basis of DMI, milk yield, or ECM yield. Effects of DFM products on methane emission have been mainly studied in vitro. Lila et al. (2004) reported that a strain of $S$. cerevisiae (twin strain 8417 and 1026; $5 \times 10^{9}$ live organisms/g) linearly decreased methane emission after a 24 -h incubation in a batch culture system where sudangrass hay and concentrates (60.5:39.5) were used as substrates. In a study by Lynch and Martin (2002), S. cerevisiae $(0.35 \mathrm{~g} / \mathrm{L} ; 5$ $\times 10^{6} \mathrm{cfu}$ ) decreased methane emission by $20.2 \%$ after $48 \mathrm{~h}$ incubation of buffered rumen fluid with alfalfa hay as a substrate, although methane emission was not affected when the substrate was ground corn, soluble starch, or bermudagrass. Similarly, S. cerevisiae (0.1 to $2.0 \mathrm{~g} / \mathrm{L}$ ) linearly decreased methane emission when expressed per digested $\mathrm{DM}(\mathrm{mL} / \mathrm{g})$, when perennial ryegrass was used as a substrate (O'Brien et al., 2014). The mode of action of yeast on methane emission is not well defined. According to Chaucheyras et al. (1995), $S$. cerevisiae stimulated hydrogen utilization of acetogenic bacteria and decreased methane emission in pure culture or in coculture. Gong et al. (2018) reported in a recent study that $S$. cerevisiae supplementation increased acetogen numbers and decreased methanogenesis in the large intestines of pigs. These promising effects of DFM from in vitro and nonruminant studies, however, have not been replicated in vivo with ruminants. Doreau and Jouany (1998) reported that dietary supplementation of $S$. cerevisiae (CNCM I-1077; $3 \times 10^{10} \mathrm{cfu} / \mathrm{d}$ per head) did not affect enteric methane emission in early lactation dairy cows fed a corn silage-based diet. Only 4 cows were used in that experiment and carbon dioxide and hydrogen emissions were also not affected by treatment (Doreau and Jouany, 1998). In another experiment with nonlactating dairy cows, 2 different strains of $S$. cerevisiae $\left(1 \times 10^{10} \mathrm{cfu} / \mathrm{d}\right.$ per head $)$ had no effect 
Table 2. Effects of a Saccharomyces cerevisiae-based direct-fed microbial product and an exogenous enzyme product on enteric gas emissions in dairy cows

\begin{tabular}{lccccc}
\hline & \multicolumn{3}{c}{ Treatment $^{1}$} & & $\begin{array}{c}P \text {-value } \\
\text { Treatment }\end{array}$ \\
\cline { 2 - 4 } Item & Control & SDM & ENZ & SEM $^{2}$ & Treatm \\
\hline Methane, g/d & 337 & 351 & 359 & 16.2 & 0.42 \\
Methane, g/kg of DMI & 13.3 & 13.7 & 14.5 & 0.58 & 0.16 \\
Methane, g/kg of milk yield & 8.47 & 8.49 & 8.98 & 0.356 & 0.51 \\
Methane, g/kg of ECM & 9.26 & 9.23 & 10.1 & 0.417 & 0.13 \\
Carbon dioxide, g/d & 12,219 & 11,907 & 11,841 & 281.2 & 0.32
\end{tabular}

${ }^{1} \mathrm{SDM}=$ Saccharomyces cerevisiae-based direct-fed microbial product at $28 \mathrm{~g} / \mathrm{cow}$ per day; ENZ = exogenous enzyme product at $10 \mathrm{~g} / \mathrm{cow}$ per day.

${ }^{2}$ Highest SEM shown; $\mathrm{n}=44$ for all variables ( $\mathrm{n}$ represents number of observations used in the statistical analysis).

on methane emission measured using the $\mathrm{SF}_{6}$ tracer technique (Chung et al., 2011). Muñoz et al. (2017) also reported that $S$. cerevisiae (CNCM I-1077; $2 \times 10^{10}$ $\mathrm{cfu} / \mathrm{d})$ did not affect methane emission or intensity in early lactation dairy cows fed a grass silage-based diet and 2 levels of concentrate (300 and $600 \mathrm{~g} / \mathrm{kg}$ of DM). These reports are in agreement with methane emission data from the current study. Other experiments using beef cattle and sheep also showed no effects of $S$. cerevisiae-based DFM on methane emission (Mathieu et al., 1996; McGinn et al., 2004). Thus, there is an apparent discrepancy between in vitro and in vivo results when dietary interventions to mitigate enteric methane are studied. Limitations of in vitro systems to study rumen fermentation have been extensively discussed and include accumulation of fermentation end products, decreased concentration of VFA and fiber degradability, and protozoa disappearance (Hristov et al., 2012; Oh and Hristov, 2016).

Studies on the effects of EXE on enteric methane production are limited and results are equivocal, with a similar discrepancy between in vitro and in vivo responses. Tang et al. (2013) tested 3 fungal (Neocallimastix patriciarum, Trichoderma longibrachiatum, and Trichoderma reesei) cellulase products at different doses $(0,12,37$, and $62 \mathrm{IU} / \mathrm{g}$ of $\mathrm{DM})$ in an in vitro batch culture system and reported that the EXE products linearly or quadratically decreased methane emission per unit of degraded DM. Dietary supplementation of cellulase and xylanase decreased or tended to decrease methane emission expressed per unit of ADF or NDF intake in growing goats, although total daily methane emission was similar among treatments (Lu et al., 2015). In a study with dairy cows, supplementation of an EXE product containing cellulase, xylanase, and esterase decreased estimated methane production (Arriola et al., 2011). In the latter study, however, methane emission was estimated based on VFA concentrations, which is not a reliable approach (Robinson et al., 2010). Other studies reported that EXE did not decrease enteric methane emission. Mohamed et al. (2017), for example, reported in an in vitro study that an EXE mixture consisting of $\beta$-glucanase, xylanase, and cellulase did not affect methane emission. He et al. (2015) reported that xylanase increased methane emission in vitro with rice straw and grass as substrates, whereas no effect was observed with corn stover. In dairy cows, dietary supplementation of a fibrolytic EXE mixture containing endoglucanase and xylanase $(1.0 \mathrm{~mL} / \mathrm{kg}$ of $\mathrm{DM})$ increased methane emission and methane yield and intensity (Chung et al., 2012). To our knowledge, the current study is the first report on the effect of an EXE containing both amylolytic and fibrolytic activities on methane emission in lactating dairy cows. Overall, it appears that responses in methane emission to EXE supplementation may depend on the type of enzyme activity, dose rate, and diet ingredient composition or type of substrate.

\section{Milk Production and Total-Tract Digestibility}

Feed intake, milk production and composition, and BW data are shown in Table 3. Treatments had no effects on DMI. Compared with the control, milk yield was increased $(P=0.05)$ by SDM but unaffected by ENZ. Feed efficiency was similar among treatments. Milk composition and BW were also not affected by treatment. Apparent total-tract digestibilities of DM, $\mathrm{OM}, \mathrm{CP}, \mathrm{NDF}, \mathrm{ADF}$, and starch were similar among treatments (Table 4). Positive effects of DFM on milk production have been reported in the past (Desnoyers et al., 2009; de Ondarza et al., 2010). Nocek and Kautz (2006) reported increased milk yield in dairy cows receiving $2 \mathrm{~g} / \mathrm{d}$ of a DFM product containing $5 \times 10^{9}$ cfu of $S$. cerevisiae and $5 \times 10^{9}$ cfu of Enterococcus faecium. Ruminal infusion of a mixture of $S$. cerevisiae and Enterococcus faecium ( $80 \mathrm{mg} / \mathrm{kg}$ of DMI) alleviated the milk yield drop during a subacute ruminal acidosis 
Table 3. Effects of a Saccharomyces cerevisiae-based direct-fed microbial product and an exogenous enzyme product on feed intake and milk yield and composition in dairy cows

\begin{tabular}{|c|c|c|c|c|c|}
\hline \multirow[b]{2}{*}{ Item } & \multicolumn{3}{|c|}{ Treatment $^{1}$} & \multirow[b]{2}{*}{$\mathrm{SEM}^{2}$} & \multirow{2}{*}{$\begin{array}{l}P \text {-value } \\
\text { Treatment }\end{array}$} \\
\hline & Control & SDM & ENZ & & \\
\hline DMI, kg/d & 25.3 & 25.6 & 25.0 & 0.95 & 0.58 \\
\hline Milk yield, $\mathrm{kg} / \mathrm{d}$ & $39.8^{\mathrm{b}}$ & $41.8^{\mathrm{a}}$ & $41.0^{\mathrm{ab}}$ & 2.03 & 0.05 \\
\hline Feed efficiency, ${ }^{3} \mathrm{~kg} / \mathrm{kg}$ & 1.59 & 1.62 & 1.63 & 0.041 & 0.31 \\
\hline Milk fat, $\%$ & 3.57 & 3.45 & 3.46 & 0.178 & 0.66 \\
\hline Milk fat yield, $\mathrm{kg} / \mathrm{d}$ & 1.48 & 1.47 & 1.51 & 0.121 & 0.89 \\
\hline $\mathrm{ECM}^{4}$ yield, $\mathrm{kg} / \mathrm{d}$ & 37.7 & 38.1 & 38.2 & 2.27 & 0.88 \\
\hline ECM feed efficiency, $\mathrm{kg} / \mathrm{kg}$ & 1.48 & 1.49 & 1.49 & 0.047 & 0.94 \\
\hline Milk true protein, $\%$ & 3.04 & 3.04 & 2.98 & 0.062 & 0.49 \\
\hline Milk true protein yield, $\mathrm{kg} / \mathrm{d}$ & 1.23 & 1.29 & 1.27 & 0.076 & 0.51 \\
\hline Milk lactose, $\%$ & 4.89 & 4.84 & 4.79 & 0.068 & 0.35 \\
\hline Milk lactose yield, $\mathrm{kg} / \mathrm{d}$ & 2.00 & 2.06 & 2.05 & 0.098 & 0.73 \\
\hline Other solids, \% & 5.26 & 5.23 & 5.25 & 0.043 & 0.43 \\
\hline Total solids, $\%$ & 11.2 & 11.1 & 11.1 & 0.14 & 0.84 \\
\hline MUN, mg/100 mL & 10.8 & 10.5 & 11.2 & 0.43 & 0.46 \\
\hline $\mathrm{SCC},{ }^{5} \times 10^{3}$ cells $/ \mathrm{mL}$ & 54.9 & 64.1 & 59.4 & 11.04 & 0.56 \\
\hline $\mathrm{BW}, \mathrm{kg}$ & 624 & 629 & 625 & 13.1 & 0.12 \\
\hline \multicolumn{6}{|c|}{$\overline{\mathrm{a}, \mathrm{b}}$ Means with different superscript letters differ at $P<0.05$} \\
\hline \multicolumn{6}{|c|}{$\begin{array}{l}{ }^{1} \mathrm{SDM}=\text { Saccharomyces cerevisiae-based direct-fed microbial product at } 28 \mathrm{~g} / \text { cow per day; ENZ = exogenous } \\
\text { enzyme product at } 10 \mathrm{~g} / \mathrm{cow} \text { per day. }\end{array}$} \\
\hline \multicolumn{6}{|c|}{$\begin{array}{l}{ }^{2} \text { Highest SEM shown; } \mathrm{n}=292 \text { for DMI, } \mathrm{n}=279 \text { for milk yield, } \mathrm{n}=277 \text { for feed efficiency, } \mathrm{n}=266 \text { for BW } \\
\text { and } \mathrm{n}=41 \text { for milk composition data }(\mathrm{n} \text { represents number of observations used in the statistical analysis). } \\
{ }^{3} \text { Milk yield/DMI. } \\
{ }^{4} \mathrm{ECM}(\mathrm{kg} / \mathrm{d})=\text { milk production }(\mathrm{kg} / \mathrm{d}) \times(383 \times \% \text { fat }+242 \times \% \text { true protein }+165.4 \times \% \text { lactose } \\
20.7) / 3,140 \text { (Sjaunja et al., } 1990) \text {. }\end{array}$} \\
\hline
\end{tabular}

challenge in dairy cows (Chiquette et al., 2015). In a recent study with 6,700 dairy cows on a commercial farm, a yeast product $(3 \mathrm{~g} / \mathrm{d}$ per head providing $6 \times$ $10^{11} \mathrm{cfu}$ ) increased milk yield by $0.7 \mathrm{~kg} / \mathrm{d}$ (Rossow et al., 2018). A meta-analysis of 14 research trials (160 observations) concluded that dietary supplementation of $S$. cerevisiae increased milk yield by $1.2 \mathrm{~kg} / \mathrm{d}$ (de Ondarza et al., 2010). It has been suggested that the response in milk production in some of these studies was due to increased ruminal fiber degradability by DFM (see the review of Chaucheyras-Durand et al., 2008). Live yeast reportedly increased NDF digestibility in situ and in vivo (Guedes et al., 2008; DehghanBanadaky et al., 2013). According to Newbold et al. (1996), some strains of $S$. cerevisiae scavenge oxygen in ruminal fluid, which may enhance fibrolytic activities, as evident by increased cellulolytic bacterial population. Additionally, yeast supplementation reportedly increased ruminal $\mathrm{pH}$ by stimulating lactate-utilizing bacteria, which is beneficial for the growth of cellulolytic bacteria (Chaucheyras-Durand et al., 2008). The increase in milk yield by SDM in the current experiment was apparently not a result of increased DMI or nutrient digestibilities. It is possible that the increase in ruminal total VFA concentration by SDM (assuming this corresponds to an increase in VFA production; Sutton et al., 2003) reflects increased energy supply to the animal, which would explain the increased milk production at a similar DMI. Another possible explanation is that SDM may have stimulated the immune system of the cows (McAllister et al., 2011), which may have positively affected productivity in the current experiment. Dietary supplementation of $S$. cerevisiae reportedly regulated immune functions by decreasing bacterial colonization in pigs and increasing acute phase proteins in beef cattle (Emmanuel et al., 2007; Lessard et al., 2009). The milk production response in the current study, however, should be interpreted with caution because ECM and milk composition were not affected by SDM.

Milk production responses to EXE have not been consistent (Beauchemin and Holtshausen, 2011; Adesogan et al., 2014; Sujani and Seresinhe, 2015). In a production study with 28 lactating cows, for example, dietary supplementation of amylase $(0.88 \mathrm{~mL} / \mathrm{kg}$ of DM) increased milk production and total-tract apparent digestibility of DM, OM, and NDF (Klingerman et al., 2009). Interestingly, a higher dose ( $4.4 \mathrm{~mL} / \mathrm{kg}$ of DM) did not affect milk yield and digestibility in the same study, which indicated that the responses to EXE could be dose-dependent. Andreazzi et al. (2018) recently reported that an amylase supplementation increased milk yield in cows fed a diet including $32 \%$ starch, which was higher than the dietary starch level in the current study 
(26.7\% DM). Other production studies with dairy cows, however, reported no effect of amylase supplementation on milk yield although DM, CP, ADF, and NDF digestibilities were increased (Gencoglu et al., 2010; Weiss et al., 2011). Studies with fibrolytic EXE have also shown variable production effects in dairy cows. Fibrolytic EXE increased milk yield in some studies (Kung et al., 2000; El-Bordeny et al., 2015; Arriola et al., 2017), but had no effect in others (Elwakeel et al., 2007; Arriola et al., 2011; Peters et al., 2015). The meta-analysis by Arriola et al. (2017) concluded that EXE slightly increased total-tract DM and NDF digestibility (by 1.4 to $2.3 \%$ ) and improved milk production (by $0.8 \mathrm{~kg} / \mathrm{d}$ ) and milk components in dairy cows, but the responses were largely variable. Gado et al. (2009) reported that an EXE mixture (7.1 units/g of cellulase, 2.3 units/g of xylanase, 61.5 units/g of $\alpha$-amylase, and 29.2 units/g of proteases) increased milk yield in early lactating cows, likely because of increased DMI and digestibility. Variation in production responses to EXE could be attributed to differences in dose and enzyme properties, diet, and experimental design (Beauchemin et al., 2003; Adesogan et al., 2014).

\section{Ruminal Fermentation}

Compared with the control, both SDM and ENZ increased total VFA concentration in ruminal fluid and, in the case of SDM, this resulted in corresponding decrease in ruminal pH (Table 5). Treatments had no other effects on rumen fermentation. Effects of DFM on ruminal fermentation in dairy cows have been inconsistent (Chaucheyras-Durand et al., 2008). Chiquette et al. (2015) and Malekkhahi et al. (2016) reported that dietary supplementation of DFM products containing S. cerevisiae $\left(2 \times 10^{9}\right.$ and $2 \times 10^{10} \mathrm{cfu} / \mathrm{d}$, respectively) increased or tended to increase ruminal $\mathrm{pH}$ in dairy cows during subacute ruminal acidosis challenge and had no effect on VFA concentrations. However, AmbrizVilchis et al. (2017) observed no effect of $S$. cerevisiae $\left(1 \times 10^{10}\right.$ or $\left.6 \times 10^{10} \mathrm{cfu} / \mathrm{d}\right)$ on ruminal $\mathrm{pH}$ in cows fed a standard or acidogenic diet in a series of experiments. Chung et al. (2011) compared 2 strains of $S$. cerevisiae and reported that one strain (CNCM I-1077) decreased ruminal $\mathrm{pH}$ and increased propionate concentration compared with the control, which is in agreement with results in the current experiment, whereas the other strain (details were not provided) had no effects on ruminal fermentation in dairy cows.

Effects of EXE on ruminal fermentation have also been inconsistent. For example, Tricarico et al. (2005) reported that an Aspergillus oryzae extract containing $\alpha$-amylase (0 to 720 dextrinizing units/kg of DM) tended to linearly increase acetate and decrease propionate molar proportions in lactating dairy cows. Hristov et al. (2008) reported no effect of EXE (amylases, xylanases, and an amylase/xylanase combination) on ruminal fermentation in dairy cows. Nozière et al. (2014), however, observed a decrease in acetate and an increase in propionate concentrations with amylase supplementation (10 g/d per cow; 300 kilo novo units) in dairy cows fed a $30 \%$ starch diet. The supplementation of amylase did not affect individual VFA when cows were fed a lower starch diet (20\% DM) in the same study. In contrast, Andreazzi et al. (2018) reported no effects of amylase produced by Bacillus licheniformis (300 kilo

Table 4. Effects of a Saccharomyces cerevisiae-based direct-fed microbial product and an exogenous enzyme product on apparent total-tract digestibility of nutrients in dairy cows

\begin{tabular}{lccccc}
\hline & \multicolumn{3}{c}{ Treatment $^{1}$} & & \\
\cline { 2 - 3 } Item & Control & SDM & ENZ & SEM $^{2}$ & $\begin{array}{c}P \text {-value } \\
\text { Treatment }\end{array}$ \\
\hline Intake, kg/d & 24.2 & 23.9 & 23.3 & 1.28 & 0.46 \\
DM & 22.5 & 22.2 & 21.6 & 1.19 & 0.46 \\
OM & 4.37 & 4.31 & 4.20 & 0.233 & 0.48 \\
CP & 6.87 & 6.79 & 6.61 & 0.364 & 0.47 \\
NDF & 4.63 & 4.57 & 4.45 & 0.244 & 0.46 \\
ADF & 6.45 & 6.37 & 6.21 & 0.339 & 0.45 \\
Starch & & & & & \\
Apparent digestibility, \% & 71.9 & 71.5 & 71.7 & 0.30 & 0.51 \\
DM & 72.7 & 72.3 & 72.5 & 0.33 & 0.67 \\
OM & 71.0 & 70.7 & 70.8 & 0.42 & 0.83 \\
CP & 47.1 & 46.8 & 46.9 & 0.51 & 0.87 \\
NDF & 39.4 & 39.9 & 40.0 & 0.98 & 0.85 \\
ADF & 99.0 & 99.0 & 99.1 & 0.09 & 0.44 \\
Starch & & & & & \\
\hline
\end{tabular}

${ }^{1} \mathrm{SDM}=$ Saccharomyces cerevisiae-based direct-fed microbial product at $28 \mathrm{~g} / \mathrm{cow}$ per day; ENZ = exogenous enzyme product at $10 \mathrm{~g} / \mathrm{cow}$ per day.

${ }^{2}$ Highest SEM shown; $\mathrm{n}=51$ for all variables ( $\mathrm{n}$ represents number of observations used in the statistical analysis). 
Table 5. Effects of a Saccharomyces cerevisiae-based direct-fed microbial product and an exogenous enzyme product on ruminal fermentation in dairy cows

\begin{tabular}{|c|c|c|c|c|c|}
\hline \multirow[b]{2}{*}{ Item } & \multicolumn{3}{|c|}{ Treatment $^{1}$} & \multirow[b]{2}{*}{$\mathrm{SEM}^{2}$} & \multirow{2}{*}{$\begin{array}{c}P \text {-value } \\
\text { Treatmen }\end{array}$} \\
\hline & Control & SDM & ENZ & & \\
\hline Ruminal pH & $6.19^{\mathrm{a}}$ & $6.08^{\mathrm{b}}$ & $6.14^{\mathrm{ab}}$ & 0.033 & 0.02 \\
\hline Ammonia, $\mathrm{m} M$ & 3.22 & 3.26 & 3.40 & 0.301 & 0.87 \\
\hline Total VFA, ${ }^{3} \mathrm{~m} M$ & $94.7^{\mathrm{c}}$ & $101.2^{\mathrm{a}}$ & $97.9^{\mathrm{b}}$ & 2.69 & 0.002 \\
\hline \multicolumn{6}{|l|}{ VFA as $\%$ of total } \\
\hline Acetate & 62.0 & 62.0 & 61.1 & 1.46 & 0.19 \\
\hline Propionate & 22.5 & 21.7 & 22.5 & 1.79 & 0.52 \\
\hline Butyrate & 12.2 & 12.8 & 12.7 & 0.21 & 0.13 \\
\hline Isobutyrate & 0.58 & 0.56 & 0.61 & 0.037 & 0.62 \\
\hline Valerate & 1.73 & 1.78 & 1.79 & 0.035 & 0.43 \\
\hline Isovalerate & 0.99 & 1.07 & 1.38 & 0.191 & 0.24 \\
\hline Acetate:propionate & 2.83 & 2.91 & 2.85 & 0.298 & 0.80 \\
\hline Protozoa, ${ }^{4} \times 10^{4} / \mathrm{mL}$ & 88.9 & 82.4 & 104.6 & 11.09 & 0.18 \\
\hline
\end{tabular}

${ }^{a-c}$ Means with different superscript letters differ at $P<0.05$.

${ }^{1} \mathrm{SDM}=$ Saccharomyces cerevisiae-based direct-fed microbial product at $28 \mathrm{~g} / \mathrm{cow}$ per day; ENZ = exogenous enzyme product at $10 \mathrm{~g} / \mathrm{cow}$ per day.

${ }^{2}$ Highest SEM shown; $\mathrm{n}=15$ for protozoa and $\mathrm{n}=25$ for all other variables ( $\mathrm{n}$ represents number of observations used in the statistical analysis).

${ }^{3}$ Treatment $\times$ time interaction, $P=0.06$.

${ }^{4}$ Statistical analysis performed on $\log _{10}$-transformed data.

novo units) on ruminal VFA production in dairy cows fed $32 \%$ starch. Responses to dietary supplementation of fibrolytic EXE have also varied among studies. A fibrolytic EXE product containing xylanase, endoglucanase, and exoglucanase activities increased total VFA concentration and tended to decrease acetate proportion in the rumen of dairy cows (Arriola et al., 2011). Similar products containing xylanase and endoglucanase activities, however, did not affect ruminal fermentation in other studies with dairy cows (Peters et al., 2010; Chung et al., 2012). The observed increase in total VFA concentration with both SDM and ENZ in the current experiment suggests enhanced fermentation in the rumen and potentially greater postruminal supply of energy for productive purposes, which could explain the observed response in milk yield with SDM.

\section{Excretion of Nitrogen and Purine Derivatives}

Excretion of urinary total-, urea-, and fecal-N and secretion of milk- $\mathrm{N}$ were not different among treatments (Table 6). Treatments also did not affect urine output or urinary $\mathrm{PD}$ excretion in the current experiment. Studies that investigated the effects of DFM or EXE on excretion of urinary- or fecal-N, or both, in dairy cows are limited. Dietary supplementation of a strain of S. cerevisiae $\left(5 \times 10^{10} \mathrm{cfu} / \mathrm{d} ; \mathrm{CNCM} \mathrm{I}-4407\right)$ increased $\mathrm{N}$ digestibility and decreased fecal-N excretion in dairy cows fed a diet containing a low level of RDP (Julien et al., 2015). Fecal-N excretion and digestibility, however, were not affected by treatment when an adequate RDP diet was fed (Julien et al., 2015), which is in agreement with results from the study by Muñoz et al. (2017) and the current experiment. Knowlton et al. (2007) reported a decrease in fecal- $\mathrm{N}$ excretion with an EXE product containing cellulase and phytase activities, which the authors attributed to improved apparent digestibility of dietary N. The lack of effect of treatment on PD excretion in the current experiment is consistent with other studies of DFM (Julien et al., 2015) and EXE (Gado et al., 2009; Andreazzi et al., 2018) in dairy cows.

\section{CONCLUSIONS}

In this experiment, dietary supplementation of a $S a c$ charomyces cerevisiae-based DFM and an EXE extract from Aspergillus oryzae and Aspergillus niger had no effect on enteric methane emission, total-tract digestibility of nutrients, or $\mathrm{N}$ excretion and secretion. Both SDM and ENZ increased total VFA concentration in ruminal fluid, which, in the case of SDM, may help explain the increased milk yield with that treatment compared with the control. The milk production response with SDM, however, should be interpreted with caution because ECM and milk composition were not different from the control.

\section{ACKNOWLEDGMENTS}

This work was supported by the USDA National Institute of Food and Agriculture Federal Appropriations under Project PEN 04539 and Accession number 
Table 6. Effects of a Saccharomyces cerevisiae-based direct-fed microbial product and an exogenous enzyme product on nitrogen excretion and secretion and urinary excretion purine derivatives in dairy cows

\begin{tabular}{lccccc}
\hline & \multicolumn{3}{c}{ Treatment $^{1}$} & & \\
\cline { 2 - 4 } Item & Control & SDM & ENZ & SEM $^{2}$ & $\begin{array}{c}P \text {-value } \\
\text { Treatment }\end{array}$ \\
\hline N intake, g/d & 719 & 706 & 692 & 38.3 & 0.56 \\
N secretion and excretion, g/d & 192 & 190 & 191 & 12.8 & 0.98 \\
Urine N & 129 & 139 & 140 & 9.3 & 0.19 \\
Urea-N & 208 & 205 & 203 & 13.1 & 0.85 \\
Fecal N & 400 & 396 & 394 & 24.3 & 0.92 \\
Total excreta N & 197 & 207 & 203 & 12.1 & 0.51 \\
Milk N & 27.1 & 27.4 & 28.0 & 1.27 & 0.91 \\
As proportion of N intake, \% & 28.9 & 29.2 & 29.2 & 0.47 & 0.89 \\
Urine N & 56.0 & 56.5 & 57.2 & 1.39 & 0.87 \\
Fecal N & 27.6 & 28.5 & 29.3 & 1.16 & 0.38 \\
Total excreta N & 20.9 & 21.9 & 20.7 & 1.17 & 0.41 \\
Milk N & & & & & \\
Urine output, kg/d & 408 & 389 & 422 & 29.0 & 0.55 \\
Urinary PD ${ }^{3}$ excretion & 53.7 & 51.8 & 48.2 & 3.64 & 0.15 \\
Allantoin, mmol/d & 462 & 441 & 470 & 31.9 & 0.64 \\
Uric acid, mmol/d & & & & \\
Total PD, mmol/d & & & & & \\
\hline
\end{tabular}

${ }^{1} \mathrm{SDM}=$ Saccharomyces cerevisiae-based direct-fed microbial product at $28 \mathrm{~g} / \mathrm{cow}$ per day; $\mathrm{ENZ}=$ exogenous enzyme product at $10 \mathrm{~g} / \mathrm{cow}$ per day.

${ }^{2}$ Highest SEM shown; $\mathrm{n}=45$ for all variables ( $\mathrm{n}$ represents number of observations used in the statistical analysis).

${ }^{3}$ Purine derivatives.

1000803. The authors thank PMI Nutritional Additives (Arden Hills, MN) for providing partial financial support and the dietary supplements for this project and the staff of The Pennsylvania State University's Dairy Teaching and Research Center for their conscientious care of the experimental cows.

\section{REFERENCES}

Adesogan, A. T., Z. X. Ma, J. J. Romero, and K. G. Arriola. 2014. Ruminant Nutrition Symposium: Improving cell wall digestion and animal performance with fibrolytic enzymes. J. Anim. Sci. 92:1317-1330.

Ambriz-Vilchis, V., N. S. Jessop, R. H. Fawcett, M. Webster, D. J. Shaw, N. Walker, and A. I. Macrae. 2017. Effect of yeast supplementation on performance, rumination time, and rumen $\mathrm{pH}$ of dairy cows in commercial farm environments. J. Dairy Sci. 100:5449-5461.

Andreazzi, A. S. R., M. N. Pereira, R. B. Reis, R. A. N. Pereira, N. N. Morais Junior, T. S. Acedo, R. G. Hermes, and C. S. Cortinhas. 2018. Effect of exogenous amylase on lactation performance of dairy cows fed a high-starch diet. J. Dairy Sci. 101:7199-7207.

AOAC International. 2000. Official Methods of Analysis. 17th ed. AOAC International, Arlington, VA.

AOAC International. 2006. Official Methods of Analysis. 18th ed. AOAC International, Arlington, VA.

Arriola, K. G., S. C. Kim, C. R. Staples, and A. T. Adesogan. 2011. Effect of fibrolytic enzyme application to low- and high-concentrate diets on the performance of lactating dairy cattle. J. Dairy Sci. 94:832-841.

Arriola, K. G., A. S. Oliveira, Z. X. Ma, I. J. Lean, M. C. Giurcanu, and A. T. Adesogan. 2017. A meta-analysis on the effect of dietary application of exogenous fibrolytic enzymes on the performance of dairy cows. J. Dairy Sci. 100:4513-4527.
Beauchemin, K. A., D. Colombatto, D. P. Morgavi, and W. Z. Yang. 2003. Use of exogenous fibrolytic enzymes to improve feed utilization by ruminants. J. Anim. Sci. 81:E37-E47.

Beauchemin, K. A., and L. Holtshausen. 2011. Developments in enzyme usage in ruminants. Pages 206-230 in Enzymes in Farm Animal Nutrition. 2nd ed. M. R. Bedford and G. G. Partridge, ed. CAB International, Wallingford, UK.

Callaway, E. S., and S. A. Martin. 1997. Effects of a Saccharomyces cerevisiae culture on ruminal bacteria that utilize lactate and digest cellulose. J. Dairy Sci. 80:2035-2044.

Chaney, A. L., and E. P. Marbach. 1962. Modified reagents for determination of urea and ammonia. Clin. Chem. 8:130-132.

Chaucheyras, F., G. Fonty, G. Bertin, and P. Gouet. 1995. In vitro $\mathrm{H}_{2}$ utilization by a ruminal acetogenic bacterium cultivated alone or in association with an archaea methanogen is stimulated by a probiotic strain of Saccharomyces cerevisiae. Appl. Environ. Microbiol. 61:3466-3467.

Chaucheyras-Durand, F., N. D. Walker, and A. Bach. 2008. Effects of active dry yeasts on the rumen microbial ecosystem: Past, present and future. Anim. Feed Sci. Technol. 145:5-26.

Chiquette, J., J. Lagrost, C. L. Girard, G. Talbot, S. Li, J. C. Plaizier, and I. K. Hindrichsen. 2015. Efficacy of the direct-fed microbial Enterococcus faecium alone or in combination with Saccharomyces cerevisiae or Lactococcus lactis during induced subacute ruminal acidosis. J. Dairy Sci. 98:190-203.

Chung, Y. H., N. D. Walker, S. M. McGinn, and K. A. Beauchemin. 2011. Differing effects of 2 active dried yeast (Saccharomyces cerevisiae) strains on ruminal acidosis and methane production in nonlactating dairy cows. J. Dairy Sci. 94:2431-2439.

Chung, Y. H., M. Zhou, L. Holtshausen, T. W. Alexander, T. A. McAllister, L. L. Guan, M. Oba, and K. A. Beauchemin. 2012. A fibrolytic enzyme additive for lactating Holstein cow diets: ruminal fermentation, rumen microbial populations, and enteric methane emissions. J. Dairy Sci. 95:1419-1427.

de Ondarza, M. B., C. J. Sniffen, L. Dussert, E. Chevaux, J. Sullivan, and N. Walker. 2010. Case Study: Multiple-study analysis of the effect of live yeast on milk yield, milk component content and yield, and feed efficiency. Prof. Anim. Sci. 26:661-666. 
Dehghan-Banadaky, M., M. Ebrahimi, R. Motameny, and S. R. Heidari. 2013. Effects of live yeast supplementation on mid-lactation dairy cows performances, milk composition, rumen digestion and plasma metabolites during hot season. J. Appl. Anim. Res. 41:137-142.

Desnoyers, M., S. Giger-Reverdin, G. Bertin, C. Duvaux-Ponter, and D. Sauvant. 2009. Meta-analysis of the influence of Saccharomyces cerevisiae supplementation on ruminal parameters and milk production of ruminants. J. Dairy Sci. 92:1620-1632.

Doreau, M., and J. P. Jouany. 1998. Effect of a Saccharomyces cerevisiae culture on nutrient digestion in lactating dairy cows. J. Dairy Sci. 81:3214-3221

El-Bordeny, N. E., A. A. Abedo, H. M. El-Sayed, E. N. Daoud, H S. Soliman, and A. E. M. Mahmoud. 2015. Effect of exogenous fibrolytic enzyme application on productive response of dairy cows at different lactation stages. Asian J. Anim. Vet. Adv. 10:226-236.

Elanthamil, R., and C. Bandeswaran. 2017. Methane emission from ruminants and its mitigating measures using probiotic - A review. Int. J. Sci. Environ. 6:319-325.

Elwakeel, E. A., E. C. Titgemeyer, B. J. Johnson, C. K. Armendariz, and J. E. Shirley. 2007. Fibrolytic enzymes to increase the nutritive value of dairy feedstuffs. J. Dairy Sci. 90:5226-5236.

Emmanuel, D. G., A. Jafari, K. A. Beauchemin, J. A. Leedle, and B. N. Ametaj. 2007. Feeding live cultures of Enterococcus faecium and Saccharomyces cerevisiae induces an inflammatory response in feedlot steers. J. Anim. Sci. 85:233-239.

Gado, H. M., A. Z. M. Salem, P. H. Robinson, and M. Hassan. 2009 Influence of exogenous enzymes on nutrient digestibility, extent of ruminal fermentation as well as milk production and composition in dairy cows. Anim. Feed Sci. Technol. 154:36-46.

Gencoglu, H., R. D. Shaver, W. Steinberg, J. Ensink, L. F. Ferraretto, S. J. Bertics, J. C. Lopes, and M. S. Akins. 2010. Effect of feeding a reduced-starch diet with or without amylase addition on lactation performance in dairy cows. J. Dairy Sci. 93:723-732.

Gong, Y. L., J. B. Liang, M. F. Jahromi, Y. B. Wu, A. G. Wright, and X. D. Liao. 2018. Mode of action of Saccharomyces cerevisiae in enteric methane mitigation in pigs. Animal 12:239-245.

Grainger, C., and K. A. Beauchemin. 2011. Can enteric methane emissions from ruminants be lowered without lowering their production? Anim. Feed Sci. Technol. 166-167:308-320.

Guedes, C. M., D. Gonçalves, M. A. M. Rodrigues, and A. Dias-daSilva. 2008. Effects of a Saccharomyces cerevisiae yeast on ruminal fermentation and fibre degradation of maize silages in cows. Anim. Feed Sci. Technol. 145:27-40.

Hall, M. B. 2009. Analysis of starch, including maltooligosacchardies, in animal feeds: A comparison of methods and a recommended method for AOAC collaborative study. J. AOAC Int. 92:42-49.

He, Z. X., L. Y. Yang, W. Z. Yang, K. A. Beauchemin, S. X. Tang, J. Y. Huang, C. S. Zhou, X. F. Han, M. Wang, J. H. Kang, N. E. Odongo, and Z. L. Tan. 2015. Efficacy of exogenous xylanases for improving in vitro fermentation of forages. J. Agric. Sci. 153:538553.

Hristov, A. N., C. E. Basel, A. Melgar, A. E. Foley, J. K. Ropp, C. W. Hunt, and J. M. Tricarico. 2008. Effect of exogenous polysaccharide-degrading enzyme preparations on ruminal fermentation and total tract digestibility of nutrients in lactating dairy cows. Anim. Feed Sci. Technol. 145:182-193.

Hristov, A. N., M. Ivan, L. M. Rode, and T. A. McAllister. 2001. Fermentation characteristics and ruminal ciliate protozoal populations in cattle fed medium- or high-concentrate barley-based diets. J. Anim. Sci. 79:515-524.

Hristov, A. N., C. Lee, T. Cassidy, M. Long, K. Heyler, B. Corl, and R. Forster. 2011. Effects of lauric and myristic acids on ruminal fermentation, production, and milk fatty acid composition in lactating dairy cows. J. Dairy Sci. 94:382-395.

Hristov, A. N., C. Lee, R. A. Hristova, P. Huhtanen, and J. Firkins. 2012. A meta-analysis of the variability in continuous culture rumen fermentation and digestibility data. J. Dairy Sci. 95:5299 5307.

Hristov, A. N., J. Oh, F. Giallongo, T. Frederick, H. Weeks, P. R. Zimmerman, M. T. Harper, R. A. Hristova, R. S. Zimmerman, and A. F. Branco. 2015. The use of an automated system (GreenFeed) to monitor enteric methane and carbon dioxide emissions from ruminant animals. J. Vis. Exp. 103:e52904. https://doi.org/ $10.3791 / 52904$.

Hristov, A. N., J. Oh, C. Lee, R. Meinen, F. Montes, T. Ott, J. Firkins, A. Rotz, C. Dell, A. Adesogan, W. Z. Yang, J. Tricarico, E. Kebreab, G. Waghorn, J. Dijkstra, and S. Oosting. 2013. Mitigation of greenhouse gas emissions in livestock production-A review of technical options for non- $\mathrm{CO}_{2}$ emission. P. Gerber, B. Henderson, and H. Makkar, ed. FAO, Rome, Italy.

Huhtanen, P., K. Kaustell, and S. Jaakkola. 1994. The use of internal markers to predict total digestibility and duodenal flow of nutrients in cattle given six different diets. Anim. Feed Sci. Technol. 48:211-227.

IPCC (Intergovernmental Panel on Climate Change). 2014. Working Group III - Mitigation of climate change. Chapter 11: Agriculture, Forestry and Other Land Use (AFOLU). Cambridge Univ. Press, Cambridge, UK.

Johnson, K. A., and D. E. Johnson. 1995. Methane emissions from cattle. J. Anim. Sci. 73:2483-2492.

Julien, C., J. P. Marden, E. Auclair, R. Moncoulon, L. Cauquil, J. L. Peyraud, and C. Bayourthe. 2015. Interaction between live yeast and dietary rumen degradable protein level: effects on diet utilization in early-lactating dairy cows. Agric. Sci. 6:1-13.

Klingerman, C. M., W. Hu, E. E. McDonell, M. C. DerBedrosian, and L. Kung Jr.. 2009. An evaluation of exogenous enzymes with amylolytic activity for dairy cows. J. Dairy Sci. 92:1050-1059.

Knowlton, K. F., M. S. Taylor, S. R. Hill, C. Cobb, and K. F. Wilson. 2007. Manure nutrient excretion by lactating cows fed exogenous phytase and cellulase. J. Dairy Sci. 90:4356-4360.

Kung, L., Jr., R. J. Treacher, G. A. Nauman, A. M. Smagala, K. M. Endres, and M. A. Cohen. 2000. The effect of treating forages with fibrolytic enzymes on its nutritive value and lactation performance of dairy cows. J. Dairy Sci. 83:115-122.

Lessard, M., M. Dupuis, N. Gagnon, E. Nadeau, J. J. Matte, J. Goulet, and J. M. Fairbrother. 2009. Administration of Pediococcus acidilactici or Saccharomyces cerevisiae boulardii modulates development of porcine mucosal immunity and reduces intestinal bacterial translocation after Escherichia coli challenge. J. Anim. Sci. 87:922-934

Lila, Z. A., N. Mohammed, T. Yasui, Y. Kurokawa, S. Kanda, and H. Itabashi. 2004. Effects of a twin strain of saccharomyces cerevisiae live cells on mixed ruminal microorganism fermentation in vitro. J. Anim. Sci. 82:1847-1854

Lopes, J. C. L. F. de Matos, M. T. Harper, F. Giallongo, J. Oh, D. Gruen, S. Ono, M. Kindermann, S. Durval, and A. N. Hristov. 2016. Effect of 3-nitrooxipropanol on ruminal fermentation, methane and hydrogen emissions, and methane isotopic signature in dairy cows. J. Dairy Sci. 99:5335-5344.

Lu, Q., J. Jiao, S. Tang, Z. He, C. Zhou, X. Han, M. Wang, J. Kang, N. E. Odongo, and Z. Tan. 2015. Effects of dietary cellulase and xylanase addition on digestion, rumen fermentation and methane emission in growing goats. Arch. Anim. Nutr. 69:251-266.

Lynch, H. A., and S. A. Martin. 2002. Effects of Saccharomyces cerevisiae culture and Saccharomyces cerevisiae live cells on in vitro mixed ruminal microorganism fermentation. J. Dairy Sci. 85:26032608.

Malekkhahi, M., A. M. Tahmasbi, A. A. Naserian, M. Danesh-Mesgaran, J. L. Kleen, O. AlZahal, and M. H. Ghaffari. 2016. Effects of supplementation of active dried yeast and malate during sub-acute ruminal acidosis on rumen fermentation, microbial population, selected blood metabolites, and milk production in dairy cows. Anim. Feed Sci. Technol. 213:29-43.

Mathieu, F., J. P. Jouany, J. Senaud, J. Bohatier, G. Bertin, and M. Mercier. 1996. The effect of Saccharomyces cerevisiae and Aspergillus oryzae on fermentations in the rumen of faunated and defaunated sheep; protozoal and probiotic interactions. Reprod. Nutr. Dev. 36:271-287.

McAllister, T. A., K. A. Beauchemin, A. Y. Alazzeh, J. Baah, R. M. Teather, and K. Stanford. 2011. Review: The use of direct fed mi- 
crobials to mitigate pathogens and enhance production in cattle. Can. J. Anim. Sci. 91:193-211.

McGinn, S. M., K. A. Beauchemin, T. Coates, and D. Colombatto. 2004. Methane emissions from beef cattle: Effects of monensin, sunflower oil, enzymes, yeast, and fumaric acid. J. Anim. Sci. 82:3346-3356.

Meale, S. J., K. A. Beauchemin, A. N. Hristov, A. V. Chaves, and T. A. McAllister. 2014. Board-Invited Review: Opportunities and challenges in using exogenous enzymes to improve ruminant production. J. Anim. Sci. 92:427-442.

Mohamed, A. E. M., C. Yangchun, B. Musa Bodinga, Z. Lixin, Y. Zekun, L. Lihui, J. Yao, R. Soomro, I. H. Abbasi, and L. Wen. 2017. Effect of exogenous fibrolytic enzymes on ruminal fermentation and gas production by RUSITEC, in vitro abomasum and ileum digestibility. Int. J. Pharmacol. 13:1020-1028.

Muñoz, C., D. A. Wills, and T. Yan. 2017. Effects of dietary active dried yeast (Saccharomyces cerevisiae) supply at two levels of concentrate on energy and nitrogen utilisation and methane emissions of lactating dairy cows. Anim. Prod. Sci. 57:656-664.

Newbold, C. J., R. J. Wallace, and F. M. McIntosh. 1996. Mode of action of the yeast Saccharomyces cerevisiae as a feed additive for ruminants. Br. J. Nutr. 76:249-261.

Nocek, J. E., and W. P. Kautz. 2006. Direct-fed microbial supplementation on ruminal digestion, health, and performance of pre- and postpartum dairy cattle. J. Dairy Sci. 89:260-266.

Nozière, P., W. Steinberg, M. Silberberg, and D. P. Morgavi. 2014. Amylase addition increases starch ruminal digestion in first-lactation cows fed high and low starch diets. J. Dairy Sci. 97:2319-2328.

NRC (National Research Council). 2001. Nutrient Requirements of Dairy Cattle. 7th rev. ed. Natl. Acad. Sci., Washington, DC.

O'Brien, M., A. Navarro-Villa, P. J. Purcell, T. M. Boland, and P. O'Kiely. 2014. Reducing in vitro rumen methanogenesis for two contrasting diets using a series of inclusion rates of different additives. Anim. Prod. Sci. 54:141-157.

Ogimoto, K., and S. Imai. 1981. Atlas of Rumen Microbiology. Japan Scientific Societies Press, Tokyo, Japan.

Oh, J., and A. N. Hristov. 2016. Effects of plant-derived bio-active compounds on rumen fermentation, nutrient utilization, immune response and productivity of ruminant animals. Pages 167-186 in Medicinal and Aromatic Crops: Production, Phytochemistry and Utilization, American Chemical Society, Washington, DC.

Oh, J., A. N. Hristov, C. Lee, T. Cassidy, K. Heyler, G. A. Varga, J. Pate, S. Walusimbi, E. Brzezicka, K. Toyokawa, J. Werner, S. S. Donkin, R. Elias, S. Dowd, and D. Bravo. 2013. Immune and production responses of dairy cows to postruminal supplementation with phytonutrients. J. Dairy Sci. 96:7830-7843.

Patra, A. K. 2016. Recent advances in measurement and dietary mitigation of enteric methane emissions in ruminants. Front. Vet. Sci. $3: 39$.
Peters, A., P. Lebzien, U. Meyer, U. Borchert, M. Bulang, and G. Flachowsky. 2010. Effect of exogenous fibrolytic enzymes on ruminal fermentation and nutrient digestion in dairy cows. Arch. Anim. Nutr. 64:221-237.

Peters, A., U. Meyer, and S. Dänicke. 2015. Effect of exogenous fibrolytic enzymes on performance and blood profile in early and midlactation Holstein cows. Anim. Nutr. 1:229-238.

Ribeiro, G. O., A. Badhan, J. Huang, K. A. Beauchemin, W. Yang, Y. Wang, A. Tsang, and T. A. McAllister. 2018. New recombinant fibrolytic enzymes for improved in vitro ruminal fiber degradability of barley straw. J. Anim. Sci. 96:3928-3942.

Robinson, D. L., J. Goopy, and R. S. Hegarty. 2010. Can rumen methane production be predicted from volatile fatty acid concentrations? Anim. Prod. Sci. 50:630-636.

Rossow, H. A., T. Riordan, and A. Riordan. 2018. Effects of addition of a live yeast product on dairy cattle performance. J. Appl. Anim. Res. 46:159-163.

Sjaunja, L. O., L. Baevre, L. Junkkarinen, J. Pedersen, and J. Setälä. 1990. A Nordic proposal for an energy corrected milk (ECM) formula. Pages 156-157 in 27th Session of the International Commission for Breeding and Productivity of Milk Animals, Paris, France. Wageningen Academic Publishers, Wageningen, the Netherlands.

Sujani, S., and R. T. Seresinhe. 2015. Exogenous enzymes in ruminant nutrition: A review. Asian J. Anim. Sci. 9:85-99.

Sutton, J. D., M. S. Dhanoa, S. V. Morant, J. France, D. J. Napper, and E. Schuller. 2003. Rates of production of acetate, propionate, and butyrate in the rumen of lactating dairy cows given normal and low-roughage diets. J. Dairy Sci. 86:3620-3633.

Tang, S. X., Y. Zou, M. Wang, A. Z. M. Salem, N. E. Odongo, C. S. Zhou, X. F. Han, Z. L. Tan, M. Zhang, Y. F. Fu, S. Q. Huang, Z X. He, and J. H. Kang. 2013. Effects of exogenous cellulase source on in vitro fermentation characteristics and methane production of crop straws and grasses. Anim. Nutr. Feed Technol. 13:489-505.

Tricarico, J. M., J. D. Johnston, K. A. Dawson, K. C. Hanson, K. R. McLeod, and D. L. Harmon. 2005. The effects of an Aspergillus oryzae extract containing alpha-amylase activity on ruminal fermentation and milk production in lactating Holstein cows. Anim. Sci. 81:365-374.

Van Soest, P. J., J. B. Robertson, and B. A. Lewis. 1991. Methods for dietary fiber, neutral detergent fiber, and nonstarch polysaccharides in relation to animal nutrition. J. Dairy Sci. 74:3583-3597.

Weiss, W. P., W. Steinberg, and M. A. Engstrom. 2011. Milk production and nutrient digestibility by dairy cows when fed exogenous amylase with coarsely ground dry corn. J. Dairy Sci. 94:2492-2499. 